\title{
Dzienniki w przestrzeni moralnej. Uwagi wstępne
}

\section{Journals in the Moral Space - Introductory Notes}

Co najmniej od połowy XX wieku narracje autobiograficzne cieszą się nad Wisłą (i nie tylko) wielką popularnością. W ostatnich latach tendencja ta zdaje się nasilać. Można to tłumaczyć zainteresowaniem „białymi plamami” w najnowszej historii Polski, bo przecież dzienniki (na przykład Jana Józefa Szczepańskiego, Jarosława Iwaszkiewicza czy Jana Józefa Lipskiego) rzucają nowe światło na konkretne wydarzenia, znane z najnowszych dziejów. Ale fascynacja ta ma zarazem inny wymiar, chyba wynika do pewnego stopnia z ciekawości dla cudzych projektów dobrego życia.

David Parker w swojej książce The Self in Moral Space: Life Narrative and the Good, której fragment publikujemy w tym numerze kwartalnika, przekonuje, że teksty autobiograficzne (także dzienniki) zawierają nieuchronnie komponent moralny. Słowo moralny ma w tym wypadku specyficzne znaczenie, bo nie wiąże się z jakąś określoną moralnością, kodeksem, deontologią. W centrum jego uwagi stoją pytania: jak być dobrym? co to znaczy być dobrym? Skupiają się one na aksjologii/dobru jako pewnym horyzoncie samorozumienia. Paul Ricœur odróżnił kiedyś etykę od moralności: „tylko umownie zachowam termin »etyka" na oznaczenie dążenia do spełnionego życia, a termin moralność na oznaczenie związku tego dążenia z normami nacechowanymi zarazem roszczeniem do powszechności i wywieraniem przymusu”'. Właśnie o tak pojmowaną etykę chodzi w dociekaniach Davida Parkera.

Parker najmocniej inspiruje się badaniami Charlesa Taylora, który dowodził w Źródtach podmiotowości, że nasza tożsamość z konieczności wiąże się z ukierunkowaniem na silnie wartościowane dobra, które wytyczają dla nas horyzont znaczenia. Taylor, a za nim Parker korzystają z zasady „najlepszego objaśnienia”

\footnotetext{
1 P. Ricour, O sobie samym jako innym, tłum. B. Chełstowski, Warszawa 2003, s. 282.
} 
$(\mathrm{NO})^{2}$, która pozwala testować sposoby naszego samorozumienia. Zasada NO nie tyle bada logiczną spójność naszych przekonań, co konfrontuje je z praktyką egzystencji. NO pokazuje, że w codziennym doświadczeniu uznajemy „realizm” wartości, co nie musi oznaczać, że wyznajemy platonizm czy innego rodzaju światopogląd, zakładający esencjalizm sfery aksjologicznej.

Parker przygląda się dwóm narracjom autobiograficznym, poddając je zasadzie NO. Analizując Autorelację Wanga Shimina i antyautobiografię Rolanda Barthes'a, dochodzi do przekonania, że „nie można usunąć bogatszych języków wartości potrzebnych autobiografom, by przeżywać swoje życie oraz o nim pisać"

Przemyślenia Parkera potraktowaliśmy jako inspirację do dyskusji na temat dzienników jako formy pisarstwa, które nieuchronnie staje się tożsamościotwórcze. Autorom tego numeru „Kontekstów Kultury” zadaliśmy kilka pytań:

- Czy rzeczywiście dzienniki, w tym zwłaszcza narracje autobiograficzne polskich pisarzy, są zapisem dążenia do jakiegoś dobra, spełnionego życia, samookreślenia na tle pewnych „moralnych ram”?

- Czy, przytaczając pytanie samego Parkera: „można zrozumiale pisać o swoim życiu i czy można zadowalająco zrozumieć takie pisarstwo bez uciekania się do gęstych antropocentrycznych języków moralnego i duchowego rozeznawania?"4.

- Czy o atrakcyjności narracji autobiograficznych decyduje w jakimś stopniu to, że podglądamy w nich czyjeś zmaganie o „spełnienie”, o sens egzystencji? Robert Piłat (Aksjologiczna nieprzejrzystość. O silnych wartościowaniach $w$ dziennikach pisarzy) pokazuje, jak może czytać narracje autobiograficzne filozof etyk. Podejmując wątki zasygnalizowane przez Parkera, zauważa, że to nie dzienniki, lecz raczej autobiografie pozwalają rozpoznać jakąś fundamentalną aksjologiczną świadomość autorów. Także Anna Głąb (Życie w brulionach. O „Dzienniku we dwoje” Jadwigi Stańczakowej) proponuje filozoficzną lekturę narracji autobiograficznych. Inaczej niż Robert Piłat (na przykładzie diariusza Jadwigi Stańczakowej) autorka dowodzi, że pisanie dziennika wiąże się z nakierowaniem ku silnie wartościowanym dobrom, gdyż jest rodzajem ćwiczenia duchowego, aktywnością służącą prowadzeniu „dobrego życia”. Tadeusz Sławek ("Ja", „my", „oni" - gramatyka opowieści o sobie. Rozważania w czasie pandemii) również skupia się na konkretnym dzienniku - na zapisie dziennikowym Samuela Pepysa z czasów zarazy panującej w Londynie w połowie XVII wieku, by zadać pytanie o słabo- i mocnowartościujące dyskursy tworzące podmiotowość jednostki w relacji do grupy. Kolejną analizę konkretnego

2 Ch. Taylor, Źródta podmiotowości. Narodziny tożsamości nowoczesnej, tłum. wielu, Warszawa 2001, s. 116.

3 D. Parker, Narracja autobiograficzna i języki dobra, tłum. A. Skucińska, „Konteksty Kultury" 2021, t. 18 , z. 1, s. 31 .

4 Tamże, s. 22. 
diariusza przynosi szkic Anny Spiechowicz (W stronę dobrego życia. Dokument osobisty w przestrzeni moralnej), która pisze o wielotomowym Dzienniku Jana Józefa Szczepańskiego. Badaczka wykorzystuje instrumentarium wypracowane przez Davida Parkera, by wskazać na te aspekty narracji autobiograficznej polskiego pisarza, które służą konstytuowaniu podmiotowości oraz artykulacji dóbr konstytutywnych.

Polemikę z tezami Parkera przeprowadza w swoim artykule Problemy z narracją Paweł Rodak, który zasadniczo zgadza się z przekonaniem, że budowanie tożsamości jest niemożliwe bez jakiegoś horyzontu wartości, ale podważa przesłanki wywodu australijskiego literaturoznawcy. Paweł Rodak między innymi kwestionuje nadrzędność piśmienno-tekstowej matrycy rozumienia człowieka i świata oraz tezę o przyczynowo-skutkowym powiązaniu świadomości etycznej z etycznym działaniem. Dyskusję z Parkerem proponuje także Anna Pekaniec, która postuluje, by ujęcie proponowane w szkicu Narracja autobiograficzna i języki dobra uzupełnić o niezbędny komponent genderowy. Sugeruje też zmianę postrzegania dzienników - przejście od ujęcia hermeneutycznego do konstrukcjonistycznego, które pozwala dostrzec dynamikę kreowania podmiotu dziennikowych notatek.

Osobne miejsce w bloku głównym zajmuje artykuł programowy Łukasza Garbala (Archeologia pamięci i podróż w czasie: edytor jako nawigator. Wezwanie do dyskusji), teoretyka i praktyka edycji tekstów autobiograficznych. Odwołując się do konkretnych przykładów (zwłaszcza dzienników Jana Józefa Lipskiego i Jana Józefa Szczepańskiego), autor zwraca uwagę na znaczną rolę komentarzy edytorskich i postuluje wypracowanie przejrzystych zasad i praktyk, które wyznaczałyby wysokie standardy opracowywania diariuszy polskich pisarzy. Prawdziwą ozdobą numeru jest początkowy fragment dzienników Romana Witolda Ingardena, z którego wynika, że filozof marzył w młodości, by zostać poetą. Dziennik Ingardena został poprzedzony edytorskim wprowadzeniem autorstwa Radosława Kuliniaka i Mariusza Pandury (Poeta sam na sam z soba - dziennik osobisty Romana Witolda Ingardena), które informuje o całym zasobie diarystycznym filozofa i wskazuje na jego główne tematy.

W numerze publikujemy dodatkowo fascynującą rozmowę Magdaleny Brodackiej z amerykańską historyczką, Marci Shore, która zajmuje się ostatnio fenomenem wschodnioeuropejskiej fenomenologii (Jan Patočka, Roman Ingarden, JózefTischner, Krzysztof Michalski) oraz dwie recenzje. W pierwszej z nich Piotr Millati omawia książę Jerzego Jarzębskiego Miasta, rzeczy, przestrzenie, którą uznaje za najbardziej osobistą w dorobku krakowskiego literaturoznawcy i krytyka. Druga, autorstwa Wojciecha Ratajczaka, dotyczy pokonferencyjnego tomu Peryferie Mitosza. Nieznane konteksty, glosy, nowe rozpoznania, który pozwala dostrzec najnowsze tendencje wciąż rozwijającej się miłoszologii. 